\title{
Importance of Microstructural Analysis in Experimental Soil Stabilization
}

\author{
Amin Chegenizadeh ${ }^{1 *}$, Mahdi Keramatikerman ${ }^{2}$ and Hamid Nikraz ${ }^{3}$ \\ ${ }^{1}$ Department of Civil Engineering, Curtin University of Technology, Australia \\ ${ }^{2}$ Graduate from Curtin University, Australia \\ ${ }^{3}$ Department of Civil Engineering, Curtin University of Technology, Australia
}

*Corresponding author: Amin Chegenizadeh, Senior Lecturer, Department of Civil Engineering, Curtin University of Technology, Kent Street, Bentley, Perth, Western Australia 6102, Australia.

Received Date: March 05, 2020

Published Date: March 10, 2020

\begin{abstract}
Microstructural analysis is an important part of the experimental soil mechanics and every laboratory soil mechanics investigation should be completed by one type of microstructural analysis. Microstructural analysis in soil mechanics encompasses to main elements of scanning electron microscopic (SEM) analysis and X-ray powder diffraction analysis (XRD). In SEM analysis, a visual presentation shows the occurred interactions between soil and or agent's particles and morphological changes are highlighted. In XRD analysis, the constituent elements of the soil and or agents are investigated. In fact, in SEM analyses physical characteristics of the microparticles are investigated, and in XRD analysis, their chemical characteristics. This study reviews a series of studies conducted in the field of geotechnical engineering and specifically in ground improvement area where the microstructural analysis has been effective in achieving robust results.
\end{abstract}

Keywords: Microstructural analysis; Soil Mechanics; SEM; EDS; XRD

\section{Introduction}

Soil stabilization is one of the interesting topics for researchers [1-8]. This process includes not limited to fibres, slag, flyash etc. Fibres been interest of many research [9-13] or slag inclusion as conducted an example by Sabbar et al. [14]. The usage of recyclable material such as sawdust conducted by Keramatikerman et al. [15]. The importance of microstructural analysis initially highlighted by Bhatia and Soliman [16]. They indicated the microparticles have an important role in shaping behavior of a soil and the soil behaviour should be investigated from this perspective. They proposed a novel method to investigate the micropores, measuring the size and number of pores that form amongst soil particles [16]. In another study, [17] highlighted mainly on methodology and importance of the sample preparation in SEM analysis. He mentioned that to achieve reliable results, this is important to keep the structure of the sample as is in the environment (i.e., undisturbed) when testing the in the device. He indicated that a small amount of soil sample is mounted on SEM device and any changes in its structure may change or mislead the analysis. Also, if the sample is wet, the factors such as shrinkage during sample preparation should be considered as it may again lead to unreliable results [17].

The importance of the Microstructural analysis has vastly been highlighted in both ground improvements and geo-environmental engineering researches [18-24]. As an example, Horpibulsuk et al. [25] Investigated effect of cement addition on stabilisation of clay during the time by performing a series of microstructural analysis. They indicated that as cement contents increase the soil particles and cement particles shape clusters, and this make less voids and stronger for the soil system. In addition to the SEM testing, they performed mercury intrusion tests to measure the pore size distributions in the soil sample [25]. In a more recent 
study [26], analyzed improvement of a specific type of clay when mixed with Portland cement (PC) and blast furnace slag (BFS) from a microstructural analysis point of view. They concluded from microstructural analysis that addition of cement generates hydration products, and this helps the voids and pores to be filled by those cementitious products and as results the strength of the soil improved. The XRD analysis also revealed that improvement of the soil strength was mainly due to increase in calcium silicate and reduction of calcium aluminate elements existing in the cement [26].

From a geo-environmental study point of view, investigated effect of BFS stabilisation on a specific type of contaminated clay by performing a series of unconfined compressive strength tests. From SEM analysis, they indicated that the slippery nature of the contamination caused the soil particles easily move and have a lower compressive strength. They also observed lower hydration products patterns in XRD analysis as another example for lower strength of contaminated soil. In another study [27], effect of zinc contamination on clay stabilized with PC were investigated. The results of SEM analysis showed that as the contamination agent increased the amount of ettringite, and hydration products reduced until it reached to zero. They also indicated that SEM and XRD analysis can successfully be utilized in study a contaminated soil [27]. In another study, [28], investigated effect of lead contamination on a clay when mixed with PC. Similarly, they indicated that addition of PC caused generation of a denser samples with lesser voids where more hydration products exist, and a stronger sample is formed as seen in SEM analysis [28].

\section{Conclusion}

In this mini review, the importance of the microstructural analysis in verification of the results in experimental soil mechanics were highlighted. This analysis usually encompasses to main types of XRD and SEM analysis to investigate chemical and physical characteristics of the soils respectively. To perform the SEM testing, sample preparation and keeping the soil integrity has a crucial role to achieve reliable results. Noting that the used sample has a very small size which should presents characteristics of the soil sample or as this is in the environment. In testing wet soil samples, this should be noted that the preparation is a time taking process and is accompany with drying the samples. As such, the soils such as clay may shrink, and their authentic characteristics may change and lead to unreliable results. As noted, the microstructural analysis has been successfully utilized in understanding the soil particles micro Behaviours and their interactions with stabilisation agents like cement and or contamination fluids.

\section{Acknowledgement}

None.

\section{Conflict of Interest}

No conflict of interest.

\section{References}

1. Andavan S, Kumar BM (2020) Case study on soil stabilization by using bitumen emulsions-A review. Materials Today: Proceedings 22: 12001202.

2. Andavan S, Pagadala VK (2020) A study on soil stabilization by addition of fly ash and lime. Materials Today: Proceedings 22: 1125-1129.

3. Jiang NJ, Du YJ, Liu K (2018) Durability of lightweight alkali-activated ground granulated blast furnace slag (GGBS) stabilized clayey soils subjected to sulfate attack. Applied Clay Science 161: 70-75.

4. Jerez LD, Gómez OE, Murillo CA (2018) Stabilization of Colombian lateritic soil with a hydrophobic compound (organosilane). International Journal of Pavement Research and Technology 11(6): 639-646.

5. Liu Y, Chang CW, Namdar A, She Y, Lin CH, et al. (2019) Stabilization of expansive soil using cementing material from rice husk ash and calcium carbide residue. Construction and Building Materials 221: 1-11.

6. Li S, Huang X, Wu S, Zhang W (2019) Experimental study of the behaviors of stabilized soil confined by polyvinyl chloride pipe. Construction and Building Materials 227: 116674.

7. Kumar JK, Kumar VP (2020) Soil stabilization using E-waste: A retrospective analysis. Materials Today, Proceedings 22: 691-693.

8. Millogo Y, Morel JC (2012) Microstructural characterization and mechanical properties of cement stabilized adobes. Materials and structures 45(9): 1311-1318.

9. Chegenizadeh A, Nikraz H (2011a) Composite soil: Fiber inclusion and strength. Advanced Materials Research 308-310: 1646-1650.

10. Chegenizadeh A, Nikraz H (2011b) Study on modulus of elasticity of reinforced clay. Advanced Materials Research 243-249: 5885-5889.

11. Chegenizadeh A, Nikraz H (2011c) Investigation on compaction characteristics of reinforced soil. Advanced Materials Research 261-263: 964-968.

12. Chegenizadeh A, Nikraz H (2011d) Investigation on strength of fiber reinforced clay. Advanced Materials Research 261-263: 957-963.

13. Chegenizadeh A, Nikraz H (2011e) Composite Clayey Sand and Short Fiber. Advanced Materials Research 383-390: 2764-2769.

14. Sabbar AS, Chegenizadeh A, Nikraz H (2017) Static liquefaction of very loose sand-slag-bentonite mixtures. Soils and Foundations 57(3): 341356.

15. Keramatikerman M, Chegenizadeh A, Nikraz H(2017a) An investigation into effect of sawdust treatment on permeability and compressibility of soil-bentonite slurry cut-off wall. Journal of Cleaner Production 162: 1-6.

16. Bhatia SK, Soliman A (1991) The application of image analysis techniques to microstructure studies in geotechnical engineering. In Microstructure of Fine-Grained Sediments. Springer, New York, USA, pp: 367-378.

17. Trzciński J (2004) Combined SEM and computerized image analysis of clay soils microstructure: technique \& application. In Advances in geotechnical engineering: The Skempton conference: Proceedings of a three-day conference on advances in geotechnical engineering, organised by the Institution of Civil Engineers and held at the Royal Geographical Society, London, UK 29-31: 654-666.

18. Chegenizadeh A, Keramatikerman M (2017) Mitigating sulphate attacks in geotechnical engineering Hauppauge, New York, USA. Nova Science Publishers, pp. 1-165.

19. Chegenizadeh A, Ashish M, Nikraz H, Keramatikerman M (2020) Sulphate Attack on Cemented-Bentonite-Coconut Coir, Results in Engineering (In publication).

20. Keramatikerman M, Chegenizadeh A, Nikraz H (2016) Effect of GGBFS and lime binders on the engineering properties of clay. Applied Clay Science 132: 722-730.

21. Keramatikerman M, Chegenizadeh A, Nikraz H (2018a) Effect of Slag on Restoration Mechanical Characteristics of Ethanol Gasoline- 
Contaminated Clay. Journal of Environmental Engineering 144(7): 06018001.

22. Keramatikerman M, Chegenizadeh A, Pu H (2017b) Effect of atrazine contamination on compressibility and permeability characteristics of clay. Geotechnical Testing Journal $40(6)$ : 936-950.

23. Keramatikerman M, Chegenizadeh A, Nikraz H, Sabbar A S (2018b) Effect of flyash on liquefaction behaviour of sand-bentonite mixture. Soils and foundations 58(5): 1288-1296.

24. Keramatikerman M, Chegenizadeh A, Yilmaz Y, Nikraz H (2018c) Effect of Lime Treatment on Static Liquefaction Behavior of Sand-Bentonite Mixtures. Journal of Materials in Civil Engineering 30(11): 06018017.

25. Horpibulsuk S, Rachan R, Chinkulkijniwat A, Raksachon Y, Suddeepong A (2010) Analysis of strength development in cement-stabilized silty clay from microstructural considerations. Construction and building materials 24(10): 2011-2021.

26. C Sekhar D, Nayak S (2019) SEM and XRD investigations on lithomargic clay stabilized using granulated blast furnace slag and cement. International. Journal of Geotechnical Engineering 13(6): 615-629.

27. Du YJ, Jiang NJ, Liu SY, Jin F, Singh DN, et al. (2014) Engineering properties and microstructural characteristics of cement-stabilized zinc-contaminated kaolin. Canadian Geotechnical Journal 51(3): 289302.

28. Pan Y, Rossabi J, Pan C, Xie X (2019) Stabilization/solidification characteristics of organic clay contaminated by lead when using cement. Journal of hazardous materials 362: 132-139. 